Journal of Educational, Health and Community Psychology

Vol 5, No 2, 2016

Iranita Hervi Mahardayani, Dhini Rama Dhania

\title{
The Efficacy of Performance Appraisal to Increase Employees' Job Satisfaction
}

\author{
Iranita Hervi Mahardayani \\ Faculty of Psychology Muria Kudus University \\ Iranita.hervi@umk.ac.id \\ Dhini Rama Dhania \\ Faculty of Psychology Muria Kudus University \\ Dhini.rama@umk.ac.id
}

\begin{abstract}
This research aims to find out the effectiveness of implementation performance appraisal toward job satisfaction of employees UMKM Bordir Dahlia in Kabupaten Kudus. Sampling was done by using population studies to 16 employees of UMKM embroidery Dahlia Kudus. The type of this research is quantitative with pra experiment approached by One group pre and posttest design method. Data analysis on this research using non parametric with different test techniques Wilcoxon t-tes. The analysis result of different test scale job satisfaction before and after handling obtained $\mathrm{Z}=-1,268$, with $\mathrm{p}=$ 0,205 ( $p>0,05$ ), so that there is no differences on job satisfaction on employees of embroidery Dahlia before and after treatment by giving performance appraisal. It means treatment by giving performance appraisal unable to increase employees job satisfaction. Therefore, the hypothesis on this research is rejected.
\end{abstract}

Keywords : performance appraisal, Job satisfaction

\section{Introduction}

Managing human resource to Small and Medium Enterprises (UKM) perhaps became one of the challenge things. The personal limitedness makes the UKM owner charged to be able to control human resource management in their companies, even most of them also establish cooperation with another parties to handle their human resource matter. Business in big as well as small scale, even if middle business, on early stage or on pioneer business must facing various problems. Some of the important problems are related to job satisfaction of employees. These problems often happen to UKM even bigger companies. Nevertheless, if these problems do not consider since the beginning then the business can be failure in the middle of journey because the employees move to another companies.

Job satisfaction of employees considered as an important factor, because it can influent the running of overall organization. The satisfation that employees felt on working is a clue that the employees have a good feeling to do their job. To employees, job satisfaction is an individual factor and tool to reach job productivity. So in human resource management scope, job satisfaction factor gives benefit for organization/company, employees, even society.

Job satisfaction of employees will grow well if the work achievement appraisal doing fairly, rational objective, and well documented. This matter is supported by Rivai's opinion (2009) stated that "people will feel satisfied or not satisfied, depends on exist or not fairness (equity) on certain situation. Especially working situation (Justice theory) "Main component on justice theory is input, result, equity, and inequity. Input is a worthed factor to employees which is considered can support their job, such as education, experience, ability, number of tasks, and 
equipment or tool to support their job. The results are considered something valuable for employees obtained from their work, such as wage or salary, fringe benefits, status symbol, reward and chance to be succeed or self actualization.

Based on those above, then need to do perfomance appraisal. Perfomance appraisal constitute employees performance apparaisal which company asses or evaluate the performance of employees working. This activity improves performance also gives feedback to the employees about the execution of work.

\section{JOB SATISFACTION AND PERFORMANCE APPRAISALS}

On this modern era, organization is charged to create high achievement of employees as a step to succeed organization development. The organization succeed influenced by various factors, human resource becomes one of it. Organization must think of the ways so that human resource or implementer can increase their working perfomance for acchieving the organization's goal. One of ways is by increasing employee satisfaction at work.

To see high or low the work perfomance achieved by employee, then it can do evaluation program of working performance held on certain periods. According to Mathis and Jackson (2006) stated that: "Evaluation of Performance Appraisal is pevaluation proccees how good the employees do their job when compared to one standard set, and then communicate it with the employees".

Job satisfaction of employees will grow well if the work achievement appraisal doing fairly, rational objective, and well documented. This matter is supported by Rivai's opinion (2009) stated that "people will feel satisfied or not satisfied, depends on exist or not fairness (equity) on certain situation. Especially working situation (Justice theory) "Main component on justice theory is input, result, equity, and inequity. Input is a worthed factor to employees which is considered can support their job, such as education, experience, ability, number of tasks, and equipment or tool to support their job. The results are considered something valuable for employees obtained from their work, such as wage or salary, fringe benefits, status symbol, reward and chance to be succeed or self actualization.

That matter supported by result of research of Inggarwati (2011), that 40,97\% Employee job satisfaction influenced by performance appraisal. Similar research also got from Ronsane (2014) there is significant inffluence between performance appraisal to employee job satisfaction food \& beverage department in Aston Braga Hotel \& Residence Bandung

\section{Hypothesis}

There is difference job satisfaction of UMKM bordir Dahlia Kudus before and after Performance Appraisal.

\section{METHOD \\ Participant}

Subject in this research is all employees of company Bordir Dahlia Kudus 16 person.

\section{Instruments}

This research using scale instrument. The scale is made based on data needed to be explored on the research. The scale is closed, where an interview be used to complete data if the respondents incomplete in filling the scale. Scale is made 5 (five) answer choice, in form favourable and unfavourable. Scale that used on this research refers to job satisfaction theory from Herzberg (Wijono, 2007) consisting of Motivator Factor and Hygeine Factor. The performance appraisal using performance appraisal aspect which is used on this research conclude, and modify from all experts opinion also adjust with place of research condition UMKM Bordir Dahlia Kudus, which include :

a. Discipline : attendance, punctuality 
Journal of Educational, Health and Community Psychology

Vol 5, No 2, 2016

Iranita Hervi Mahardayani, Dhini Rama Dhania

b. Interpersonal: communication, self control, cooperation, flexibility, social interaction.

performance appraisal can be seen on picture as below:

c. Working attitude: desire to achieve, perveserance, initiative, working speed, autonomy, systematic work, accuracy, commitment.

\section{Procedure}

This research using quantitative research with preexperiment approach. Using re-design treatment (one group pre and posttestdesign).

Table 1

Research Design

(one group preand posttestdesign)

$\begin{array}{ccr}\text { Pretest } & \text { Treatment } & \text { Post test } \\ \text { P1 } & \text { X } & \text { P2 }\end{array}$

Explanation:

P1: Test before treatment given (pretest)

$\mathrm{X}$ : Giving treatment implementation performance appraisal on experiment group

P2: Test after treatment given (posttest)

\section{RESULTS}

Base on data analysis, It is obtained result that treatment given which is implementation of performance appraisal to employees unable to increase employees job satisfaction Bordir Dahlia Kudus, visible from result of analysis different test scale job satisfaction before and after treatment obtained $Z=-1,268$, with $p=0,205$ ( $\mathrm{p}>0,05)$. The result shows no differences on job satisfation of employees Bordir Dahlia before and after given treatment performance appraisal, so that hypothesis on this research is rejected.

Comparison of job satisfaction employees between before and after treatment which is given

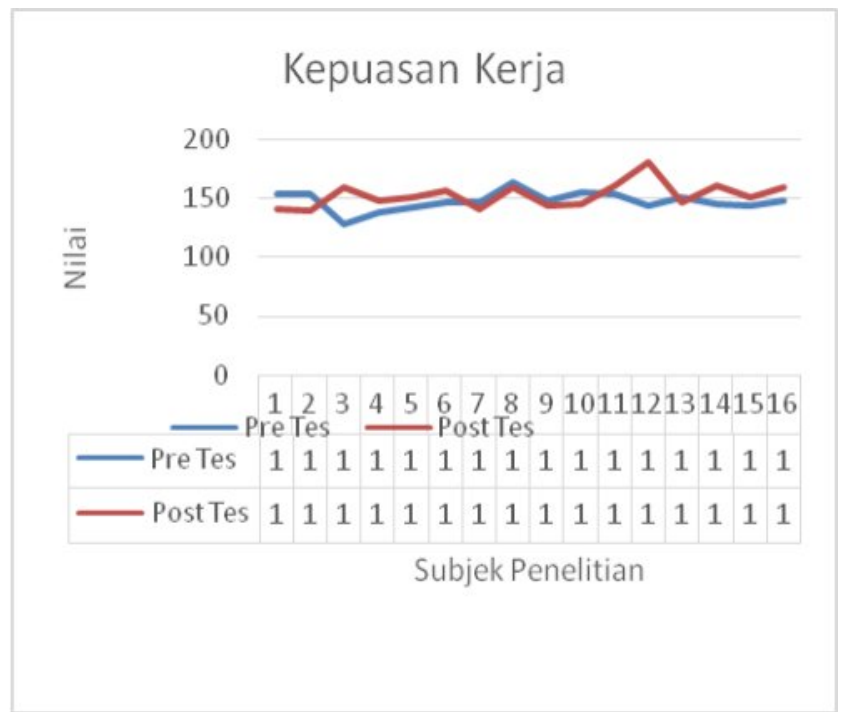

Picture 1

Comparison employees job satisfaction Between before and after treatment

From comparison result of job satisfaction between before and after treatment obtained 7 (seven) employees shows reduction job satisfaction after working assesment by their supperior, and 9 (nine) another employees shows enhancement job satisfaction. From employees show reduction of job satisfaction obtained information that become uncomfortable and hesitant when their work is rated by supperior. They also feel the unfairness on that job assesment and that performance appraisal not used for carrier enhancement. Otherwise, from employees who are enhancement in job satisfaction obtained 
information that there is performance appraisal, company condition becomes orderly, company more appreciate hard work of the employees, and can treat the employees fairly. Also from that performance appraisal, they feel giving chance to improve their performance to be better.

\section{Result}

The aim of this research is to examine empirically influence of performance appraisal to measure job satisfaction of employees UMKM Bordir Dahlia in Kabupaten Kudus. Based on data analysis known that hypothesis submitted is rejected. Seen from the analysis result of different test of job satisfaction scale before and after handling ontained $Z=-1,268$, with $p=0,205(p>0,05)$. That result shows there is difference on job satisfaction of employees Bordir Dahlia before and after treatment by giving performance appraisal.

\section{Discussion}

Job satisfaction is one of forms of behavioral outcomes employees on organization. Furthermore job satisfaction can influence working behavior such as motivation and working spirit, productivity, and working performance. (Darmawan, 2013). According to Locke (Wijono, 2010), job satisfaction is a emotional level which positive and individual pleasure. In another words, job satisfaction is a result of individual estimation towards job or positif experience and please themselves.

Effort to satisfy employee is one of company's job that simple but most complicated. According to Caugemi and Claypool (As'ad, 1998) factors that influence job satisfaction is performance, reward, promotion, compliment. While factors causing job dissatisfaction is company policy, supervisor, working condition, salary.

According to Hasibuan (1995), working performance is a working result acchieved by someone on doing the jobs given based on ability,

experience, and seriousness also time. While, according to As'ad (1995), working performance as someone's success on implementing a job. Therefore, either the company itself as well as the employees need feedback on their efforts, so working performance from each employees need to be rated.

Performance appraisal defined as a procedure which cover (1) Establish work standard (2) Assess the performance of employees significantly compares with the standard of work that has been set. (3) Providing feedback to employees to leave the poor performance and to maintain and even improve the already excellent achievement. (Gaol, 2014).

Performance appraisal should be direct and objective, means a praisser look at their employees' work related indication of performance to be assessed. (Gaol, 2014). Furthermore disclosed by Darmawan (2013) importance of performance appraisal require the assessment must be objective that measure actual employees performance, means implementation assessment must be refflect actual performance implementation.

To create job satisfaction within the employees, need to know the factors that influencing. Luthans (2011) stated five dimension which become benchmark employees job satisfaction, i.e: the job itself, salary, promotion chance, supervision, and co-worker. Moreover research of Bowra and Nasir (2014), Dhewi et al. (2006) stated that performance assessment constitute factor that influence job satisfaction.

However, through this study happened the opposites, with utterly rejected the hypothesis proposed in this study, shows that giving treatment i.e implementation of performance appraisal to employees who are not be able to increase job satisfaction Bordir Dahlia Kudus.

\section{CONCLUSION}


Journal of Educational, Health and Community Psychology

Based on research result that has been held in UMKM Bordir Dahlia Kudus, can be concluded that treatment given performance appraisal not able to increase employees' job satisfaction. Those matter seen from result of different test scale before and after treatment obtainer $\mathrm{Z}=-1,268$, with $p=0,205(p>0,05)$, so there is no difference on job satisfaction of employees in Bordir Dahlia before and after treatment by giving performance appraisal. Therefore, the hypothesis on this research is rejected.

\section{References}

Anwar Prabu Mangkunegara. 2005.Sumber Daya Manusia perusahaan. Remaja Rosdakarya: Bandung

Arikunto S, 2006. Prosedur Penelitian Suatu Pendekatan Praktik, EdRevisi VI, Penerbit PT Rineka Cipta, Jakarta.

As'ad, Moch. 1998.Psikologi Industri. Liberty, Yogyakarta.

Azwar. 2006. Reliabiltas dan Validitas.Yogyakarta : Pustaka Pelajar.

Byars, Lloyd L., Rue, Leslie W (2005). Human ResourceManagement. Ninth Edition.New York : McGraw Hill.

Blumberg \& Pringle. 1982. The Missing Opportunity in Organizational Research : Some Implications for a Theory of Work Performance. Academy of Management Review

Bowra, Z. A., \& Nasir, A. (2014). Impact of Fairness of Performance Appraisal on

Motivation and Job Satisfaction in Banking Sector of Pakistan. Journal of Basic and Applied Scientific Research, 4(2), 16-20

Caecilia Dana Risa, Haryanto F, adholan Rosyid. 2009. Pelibatan karyawan dalam proses penyusunan dan penerapan sistem penilaian kinerja dan peningkatan kepuasan

\section{Suggestion}

UMKM Bordir Dahlia Kudus can inform related to performance appraisal as well as the usage to employees, so it can increase the job satisfaction to its employees. UMKM Bordir Dahlia Kudus should do performance appraisal more objectively UMKM Bordir Dahlia Kudus can use performance appraisal as strategic goal of the company.

kerja karyawan. Program Pasca Sarjana Fakultas Psikologi Universitas Gadjah Mada. Jurnal Psikologi Volume 3, No.1, Desember 2009

Darmawan D. 2013. Prinsip-prinsip Perilaku Organisasi. Surabaya. Pena Semesta

Dessler, G. 1997. Manajemen Personalia. Teknik dan Konsep Modern. Jakarta.Erlangga

Dhewi, R. M., Mangkuprawira, S., \& Ma'arif, S. (2006). Analisis Pengaruh

Efektivitas Sistem Penilaian Kinerja terhadap Motivasi Kerja, Kepuasan Kerja dan Kinerja Karyawan PT Coats Rejo Indonesia. Jurnal Manajemen Dan Agribisnis, 3(1), 1-17.

Emzir. (2008). Metodologi Penelitian Pendidikan Kuantitatif dan Kualitatif. Jakarta: Raja Grafindo Persada.

Gaol, J. 2014. A to Z Human Capital Manajemen Sumber Daya Manusia. Jakarta. Gramedia

Gina Gunarti Ronsane, 2014. Pengaruhefektifitas penilaian kinerja terhadapkepuasan kerja karyawan food\&beverage departmentdi Aston Braga \& residence Bandung. Universitas Pendidikan Indonesia. repository.upi.edu perpustakaan.upi.edu

Hasibuan, M .1995.ManajemenSumberDaya Manusia : Dasar dan KunciKeberhasilan. Jakarta.GunungAgung 
Journal of Educational, Health and Community Psychology

Vol 5, No 2, 2016

Iranita Hervi Mahardayani, Dhini Rama Dhania

Hasibuan, M., 2007, Manajemen Sumber Daya Manusia, Jakarta .Bumi Aksara, Indonesia

Heidjrachman dan Suad Husnan. 2002. Manajemen Personalia. Yogyakarta: BPFE

Inggarwati. 2011. Effecton Performance Appraisalfor

employeesatisfactioninPT.TazkiaAuliaRaamreta z.http://pustaka.fe.unpad.ac.id/index.php/skripsi /detail/2168/pengaruh-penilaian-kinerjaterhadap-kepuasan-kerja-karyawan-padapt.tazkia-aulia-raamretaz

Kinicki, Angelo and R. Kreitner, 2005, Organizational Behavior Key concepts skills and best Practice, Mc Graw-Hill, New York, hal. 125

Luthans, F., 2005, Organizational Behavior, Mc Graw-Hill Book Co-Singapore,Singapura

Luthans, F., 2005, Organizational Behavior, Mc Graw-Hill Book Co-Singapore,Singapura, hal. 120

Luthans, F. (2011). Organizational Behavior: An Evidence-Based Approach (12th ed.). New York: McGraw-Hill/Irwin

Mangkunegara. (2005). Manajemen Sumber daya ManusiaPerusahaan.Bandung : PT Remaja Rosdakarya

Mathis, R dan Jackson, W.2006. Human Resources Development(Track MBA series/terjemahan). Jakarta; Prestasi Pustaka

Nelson, D.L., and J.C., Quick, 2006, Organizatonal Behavior Foundations Realities and Challenges, Thompson South Western, United States of America, hal. 120.

Noe, R. A. , et all, 2006, Human Resources Management, Mc Graw-Hill, New York,
Periantalo J. 2016. Penelitian Kuantitatif Untuk Psikologi. Yogyakarta. Pustaka Pelajar

Ruhana, C. $2015 . \quad$ Pengaruh penilaiankinerjaterhadapkepuasan kerja dan prestasi kerja (Studi pada Karyawan PT. Telekomunikasi Indonesia, Tbk Wilayah Malang)Jurnal Administrasi Bisnis (JAB)|Vol. 24 No. 2Juli2015

Robbins, S.P., and T.A., Judge, 2009, Organizational Behavior, Pearson Prentice Hall, United State Of America, New York

Robbins, S.P., and T.A., Judge, 2009, Organizational Behavior, Pearson Prentice Hall, United State Of America, New York

Ronsane, G. G. (2014). Pengaruh Efektivitas Penilaian Kinerja Terhadap Kepuasan Kerja Karyawan Food \& Beverage Department di Aston Braga Hotel \& Residence Bandung, (Online), (http://repository.upi.edu/13628/, diakses 15 Mei 2015).

Siswanto. (2001). SKP, Konsep, Teknik \& Kasus. PT. Damar Mulia Pustaka, Jakarta.

Susan PSP. 2007. Atribusi Karyawan Terhadap Hasil Penilaian Kinerja. Skripsi. Universitas Indonesia.

Wexley, Kenneth. and Gary Yukl. (1992). Perilaku Organisasi dan Psikologi Personalia . Jakarta: Rineka Cipta.

Williams, L. J., \& Anderson, S. E. (1991). Job satisfaction and organizational commitment as predictors of organizational citizenship and in-role behaviors. Journal of Management,

Wijono, Sutarto. 2007. Psikologi Industri dan Organisasi. Kencana : Jakarta. 
Journal of Educational, Health and Community Psychology

Vol 5, No 2, 2016

Iranita Hervi Mahardayani, Dhini Rama Dhania 